\title{
UPAYA PENGGALIAN POTENSI PAJAK PENGHASILAN DARI TRANSAKSI PENGALIHAN HAK ATAS TANAH DAN/ATAU BANGUNAN
}

\author{
Agus Bandiyono dan Melinda Fitriyani \\ Politeknik Keuangan Negara STAN \\ agusbandiyono@pknstan.ac.id
}

\begin{abstract}
This study aims to identify the imposition of income tax, analyze tax potential, explain and evaluate efforts to get the potential income tax and find out the obstacles experienced in getting the potential income tax on income from transfer of land and / or building rights transactions at KPP Pratama Wates. The research method used is the library research method and the field research method (interviews). The results of this study, in general, KPP Pratama Wates has made efforts to explore the potential income tax from transactions of transfer of rights to land and / or buildings properly. This can be seen from the suitability between the regulations and their application in the office. In addition, there are several obstacles in exploring this potential which causes the efforts to be less than optimal, such as difficulties in communicating with taxpayers, lack of authority in accessing taxpayer data which is more in-depth related to the correctness of the transaction value stated by the taxpayer, and there are still many document applied. by taxpayers who do not have an NPWP so that it is difficult to do follow-up, and there are obstacles from existing regulations. The novelty of the findings (novelty) in this study is to use a newer rule in the form of PER-26 / PJ / 2018 and discuss more deeply and evaluate the application of the $S S P-P H T B$ research procedures.
\end{abstract}

Keywords: exploration of potential; land rights and / or buildings; income tax; taxation; public sector accounting; state finances

\begin{abstract}
Abstrak
Penelitian ini bertujuan untuk mengidentifikasi pengenaan pajak penghasilan, menganalisis potensi pajak, menjelaskan dan mengevaluasi upaya penggalian potensi pajak penghasilan serta mengetahui kendala-kendala yang dialami dalam melakukan penggalian potensi pajak penghasilan atas penghasilan dari transaksi pengalihan hak atas tanah dan/atau bangunan di KPP Pratama Wates. Metode penelitian yang digunakan adalah metode deskriptif kualitatif berupa penelitian kepustakaan dan metode penelitian lapangan berupa wawancara. Hasil penelitian
\end{abstract}


Jurnal Akuntansi Berkelanjutan Indonesia - Vol. 4, No. 1, Jan 2021 - Bandiyono \& Fitriyani

ini, secara umum KPP Pratama Wates telah melakukan upaya penggalian potensi pajak penghasilan dari transaksi pengalihan hak atas tanah dan/atau bangunan dengan baik. Hal ini dapat diketahui dari kesesuaian antara peraturan dan penerapannya di lapangan. Selain itu, terdapat beberapa kendala dalam melakukan penggalian potensi ini yang menyebabkan upaya yang dilakukan menjadi kurang optimal seperti kesulitan berkomunikasi dengan Wajib Pajak, kurangnya kewenangan dalam akses data Wajib Pajak yang lebih mendalam terkait dengan kebenaran nilai transaksi yang dinyatakan Wajib Pajak, dan masih banyak berkas permohonan penelitian yang dilakukan oleh Wajib Pajak yang belum memiliki NPWP sehingga kesulitan dalam dilakukan tindak lanjut. Kebaruan temuan (novelty) dalam penelitian ini yaitu menggunakan aturan yang lebih baru berupa PER-26/PJ/2018 dan membahas lebih dalam serta mengevaluasi penerapan tata cara penelitian SSP-PHTB tersebut.

Kata kunci: penggalian potensi; Hak Atas Tanah Dan/Atau Bangunan; pajak penghasilan; perpajakan; akuntansi sektor publik; keuangan negara

\section{PENDAHULUAN}

Pajak merupakan sumber penerimaan negara terbesar di Indonesia. Berdasarkan laporan keuangan pemerintah pusat tahun 2018 (audited), persentase realisasi penerimaan dari sektor perpajakan mencapai 78,14 \% dari total realisasi penerimaan negara tahun 2018. Dalam LKPP 2018 dapat ketahui bahwa Pajak penghasilan menyumbang penerimaan paling tinggi. Adanya tren yang demikian memberikan konsekuensi kepada pemerintah, dalam hal ini Direktorat Jenderal Pajak, untuk mampu meningkatkan penerimaan dari sektor perpajakan dari tahun ke tahun dengan mengoptimalkan segala potensi yang ada termasuk potensi dari penerimaan pajak penghasilan seiring dengan perkembangan perekonomian di Indonesia.

Dikutip dari Bandiyono (2017), pembangunan belakangan ini sedang berlangsung sangat pesat guna mengurangi kesenjangan yang ada di berbagai wilayah di Indonesia. Pembangunan salah satunya terjadi di bidang infrastruktur. Pembangunan infrastruktur terjadi di berbagai tempat salah satunya di Daerah Istimewa Yogyakarta termasuk di Kabupaten Kulon Progo. Kabupaten Kulon Progo saat ini sedang mengalami perkembangan ekonomi yang pesat disebabkan oleh salah satunya adalah pembangunan Bandara Internasional Yogyakarta. Berdasarkan data laju pertumbuhan ekonomi di laman Badan Perencanaan Pembangunan Daerah, diketahui bahwa laju pertumbungan ekonomi Kabupaten Kulon Progo tahun 2018 mencapai $10,84 \%$. Kenaikan ini sangat drastis jika dibandingkan dengan laju pertumbuhan tahun 2017 yang hanya 5,97\%.

Selain laju pertumbuhan ekonominya, harga tanah di Kabupaten Kulon Progo juga mengalami peningkatan yang tajam. Berdasarkan penuturan Bupati Kabupaten 
Jurnal Akuntansi Berkelanjutan Indonesia - Vol. 4, No. 1, Jan 2021 - Bandiyono \& Fitriyani

Kulon Progo, Hasto Wardoyo, yang ditulis dalam artikel situs bisnis.com, Nilai Jual Objek Pajak (NJOP) tanah di Kabupaten Kulon Progo naik hingga 70\% setelah adanya pembangunan bandara.

Kenaikan harga tanah di Kabupaten Kulon Progo ini dapat dilihat sebagai suatu potensi penerimaan pajak terkhusus penerimaan pajak penghasilan. Pajak Penghasilan dari transaksi pengalihan hak atas tanah dan/atau bangunan diatur dalam UndangUndang Nomor 36 Tahun 2008 tentang Perubahan Keempat atas Undang-Undang Nomor 7 Tahun 1983 tentang Pajak Penghasilan Pasal 4 ayat 2 huruf d yang dipertegas menggunakan Peraturan Pemerintah Nomor 34 Tahun 2016 tentang Pajak Penghasilan atas Penghasilan dari Pengalihan Hak atas Tanah dan/atau Bangunan, Perjanjian Jual Beli atas Tanah dan/atau Bangunan Berserta Perubahannya.

Secara umum, indikasi ketidakpatuhan yang sering ditemui adalah nilai jual beli yang tidak sesuai dengan harga pasar sehingga wajib pajak menyetorkan pajaknya dalam jumlah yang tidak sesuai pula. (Warsito, 2016). Hal ini menjadi tantangan bagi KPP Pratama Wates, selaku kantor pelayanan pajak yang mengadministrasikan pajak penghasilan atas transaksi pengalihan tanah dan/atau bangunan di Kabupaten Kulon Progo, untuk mampu melakukan penggalian potensi atas transaksi tersebut sehingga dapat mengoptimalkan penerimaan pajaknya.

Tujuan penelitian ini adalah untuk mengidentifikasi pengenaan pajak penghasilan, menganalisis potensi pajak, menjelaskan dan mengevaluasi upaya penggalian potensi pajak penghasilan serta mengetahui kendala-kendala yang dialami dalam melakukan penggalian potensi pajak penghasilan atas penghasilan dari transaksi pengalihan hak atas tanah dan/atau bangunan di KPP Pratama Wates.

Kebaruan temuan (novelty) serta kontribusi penelitian ini yaitu bahwa pada penelitian ini menyajikan penjelasan atas penggalian potensi pajak penghasilan dari transaksi pengalihan hak atas tanah dan/atau bangunan. Hal lain bahwa pada penelitian ini penulis lebih fokus dalam melakukan evaluasi terhadap penerapan pengenaan pajak penghasilan setelah berlaku PP Nomor 34 Tahun 2016. Selain itu, dalam penelitian ini penulis lebih berfokus pada kontribusi penerimaan dari transaksi pengalihan tanah dan/atau bangunan dan evaluasi proses penelitian formal dan material SSP-PHTB. Selanjutnya, dalam penelitian ini menggunakan aturan yang lebih baru yaitu PER-26/PJ/2018 dan membahas lebih dalam serta mengevaluasi penerapan tata cara penelitian SSP-PHTB tersebut.

\section{KERANGKA TEORITIS DAN PENGEMBANGAN HIPOTESIS}

Pengertian pajak menurut Undang-Undang Nomor 6 Tahun 1983 sebagaimana yang telah terakhir diubah dalam Undang-Undang Nomor 16 Tahun 2009 tentang Ketentuan Umum Perpajakan menyatakan pada pasal 1 huruf 1 menyatakan bahwa pajak adalah kontribusi wajib kepada negara yang terutang oleh orang pribadi atau badan yang bersifat memaksa berdasarkan undang- 
Jurnal Akuntansi Berkelanjutan Indonesia - Vol. 4, No. 1, Jan 2021 - Bandiyono \& Fitriyani

undang, dengan tidak mendapatkan imbalan secara langsung dan digunakan untuk kepentingan negara bagi sebesar-besar kemakmuran rakyat. Selain itu para ahli juga memberikan pendapatnya mengenai pengertian pajak sebagai berikut:

1) Prof. Dr. Rachmat Soemitro, S.H. menyatakan bahwa pajak merupakan iuran atau pungutan rakyat kepada pemerintah berdasarkan undang-undang yang berlaku yang dapat dipaksakan dengan tidak mendapat kontraprestasi secara langsung serta dapat ditunjuk dan dipakai guna untuk membiayai kebutuhan pengeluaran negara. (Resmi, 2012:1)

2) S.I. Djajadinigrat menyatakan bahwa Pajak sebagai suatu kewajiban menyerahkan sebagian dari kekayaan ke kas negara yang disebabkan suatu keadaan, kejadian, dan perbuatan yang memberikan kedudukan tertentu, tetapi bukan sebagai hukuman, menurut peraturan yang ditetapkan pemerintah serta dapat dipaksakan, tetapi tidak ada jasa timbal balik dari negara secara langsung, untuk memelihara kesejahteraan secara umum. (Resmi, 2012:1)

3) Prof. Dr. P. J. A. Anriani menjelaskan pajak iuran kepada Negara (yang dapat dipaksakan) yang terutang oleh yang wajib membayarnya menurut peraturanperaturan, dengan tidak mendapat prestasi kembali, yang langsung dapat ditunjuk dan yang gunanya adalah untuk membiayai pengeluaran-pengeluaran umum berhubung dengan tugas negara untuk menyelenggarakan pemerintahan. (Waluyo, 2011:2)

4) Dr. N. J. Feldman menyatakan bahwa pajak merupakan prestasi yang dipaksakan sepihak oleh dan terhutang kepada penguasa menurut normanorma yang ditetapkan secara umum dengan tanpa adanya kontraprestasi dan semata mata digunakan untuk menutup pengeluaran-pengeluaran umum. (Waluyo, 2011:2)

5) Dr. Sopearman Soemahamidjaja menyatakan bahwa pajak merupakan iuran wajib, berupa uang atau barang, yang dapat dipungut oleh penguasa berdasarkan norma-norma hukum, guna menutup biaya produksi barangbarang dan jasa jasa kolektif dalam mencapai kesejahteraan umum. (Waluyo, 2011:2)

Jadi, dari berbagai pengertian di atas dapat diambil kesimpulan bahwa aspek pajak meliputi sebagai berikut:

1. Pajak merupakan iuran atau pungutan negara;

2. Memiliki sifat memaksa;

3. Diatur pemerintah berdasarkan peraturan perundang-undangan; dan

4. Digunakan untuk membiayai kepentingan negara untuk kesejahteraan masyarakat

Tjahjono memaparkan macam-macam pajak di Indonesia dan mendefinisikan pajak penghasilan sebagai pajak yang dikenakan kepada orang pribadi atau badan atas penghasilan yang diterima atau diperoleh dalam satu tahun Pajak. (Tjahjono, 1999). Sedangkan menurut Undang-Undang Nomor 36 Tahun 2008 tentang Pajak Penghasilan Pasal 1, Pajak Penghasilan merupakan pajak yang dikenakan terhadap Subjek Pajak atas penghasilan yang diterima atau diperolehnya dalam tahun pajak. 
Jurnal Akuntansi Berkelanjutan Indonesia - Vol. 4, No. 1, Jan 2021 - Bandiyono \& Fitriyani

Beberapa jurnal internasional yang terkait, di antaranya adalah:

Rum, M., \& Kusumawardani, A. (2020) menganalisis pengaruh pertumbuhan industri dan pengaruhnya terhadap potensi pajak pemerintah Provinsi Sulawesi Selatan. Hasil penelitian menunjukkan bahwa pertumbuhan industri berpengaruh signifikan dan positif terhadap potensi kenaikan pajak Sulawesi Selatan. Pertumbuhan objek pajak berpengaruh signifikan terhadap potensi kenaikan pajak Sulawesi Selatan. Sumber daya lingkungan berpengaruh signifikan terhadap potensi kenaikan pajak. Shahab, S., \& Viallon, F. X. (2019) menunjukkan varians biaya transaksi lintas waktu, pelaku dan aktivitas terkait penilaian atas tanah. Selain itu, terdapat bukti negosiasi seputar nilai tanah yang ada dan yang akan datang serta redistribusi hak pembangunan. Buitelaar, E. (2004) menunjukkan mengapa biaya transaksi penting dan menawarkan metode untuk mengidentifikasinya. Dengan metode yang dipakai dalam risetnya, dimungkinkan untuk membandingkan efisiensi pengaturan kelembagaan yang berbeda.

Perbedaan penelitian ini dari 3 jurnal internasional di atas yaitu bahwa pada penelitian ini menyajikan penjelasan atas penggalian potensi pajak penghasilan dari transaksi pengalihan hak atas tanah dan/atau bangunan. Adapun pada ketiga jurnal di atas, belum ada yang mengkaitkan transaksi hak atas tanah dan/atau bangunan dengan potensi pajaknya. Selain itu, beberapa jurnal nasional terdahulu terkait tema ini di antaranya adalah:

Pratama, K. B. (2019) yang ingin mengetahui kontribusi dan tingkat efektivitas Peraturan Pemerintah Nomor 34 Tahun 2016 serta dampaknya terhadap pihak terkait, yaitu pihak KPP dan WP di Kabupaten Karanganyar. Simpulan dari penelitian ini adalah meskipun terjadi penurunan pada awal PP No. 34 Tahun 2016 berlaku, namun dengan turunnya tarif meningkatkan jumlah WP yang melaporkan kegiatan pengalihannya.Irawan, F. (2018) yang melihat dampak penerapan PP nomor 34 tahun 2016 (PP 34 tahun 2016) terhadap pengalihan pajak penghasilan final atas tanah dan / atau bangunan, dan jumlah wajib pajak yang mengajukan pengesahan surat penyetoran pajak. pajak. Hasil penelitian menunjukkan bahwa penerimaan pajak cenderung menurun meskipun jumlahnya tidak signifikan. Uji berpasangan menunjukkan tidak ada perbedaan sebelum dan sesudah penerapan PP. 34 tahun 2016 baik dalam penerimaan pajak maupun validasi banding. Susyanti, J., \& Wahono, B. (2018) yang menganalisis apakah terdapat perbedaan kinerja keuangan perusahaan real estate dan properti sebelum dan selama berlakunya PP No.34 tahun 2016. Hasilnya membuktikan bahwa setelah kebijakan baru masih dalam masa transisi pada saat berlakunya PP No.34 tahun 2016 dan masih dalam penyesuaian. Oleh karena itu, belum ada peningkatan kinerja keuangan secara total dibandingkan dengan perusahaan real estat dan properti. Agustina, N. K. A. R. (2017) yang ingin melihat bagaimanakah fungsi validasi atas pajak yang telah dibayar oleh Wajib Pajak dalam pembuatan akta Perjanjian Pengikatan Jual Beli di hadapan Notaris, Bagaimanakah implikasi validasi terhadap keabsahan akta Perjanjian Pengikatan Jual Beli yang dibuat dihadapan Notaris. Hasil menunjukkan bahwa fungsi validasi bertujuan untuk 
membuat sesuatu yang resmi diterima atau disetujui, terutama setelah melakukan pemeriksaan, sedangkan verifikasi bertujuan untuk membuktikan bahwa sesuatu ada atau benar, atau untuk memastikan bahwa sesuatu adalah benar.Implikasi validasi terhadap keabsahan akta PPJB terletak pada perlindungan hukum dan kepastian hukum bagi para pihak karena diatur pada Pasal 1 ayat (1 dan 2) PP Nomor 34 tahun 2016.PP nomor 34 Tahun 2016 mengatur tentang pajak terhutang yang bersifat final atas pengalihan hak atas tanah dan/atau bangunan.

Adapun perbedaan penelitian ini dari keempat jurnal nasional di atas yaitu bahwa pada penelitian ini penulis lebih fokus dalam melakukan evaluasi terhadap penerapan pengenaan pajak penghasilan setelah berlaku PP Nomor 34 Tahun 2016.Selain itu, dalam penelitian ini penulis lebih berfokus pada kontribusi penerimaan dari transaksi pengalihan tanah dan/atau bangunan dan evaluasi proses penelitian formal dan material SSP-PHTB. Selanjutnya, dalam penelitian ini menggunakan aturan yang lebih baru yaitu PER-26/PJ/2018 dan membahas lebih dalam serta mengevaluasi penerapan tata cara penelitian SSP-PHTB tersebut.

1. Pajak merupakan sumber penerimaan negara terbesar di Indonesia. Pada tahun 2018 realisasi penerimaan pajak mencapai $78,14 \%$ dari keseluruhan penerimaan negara. (Laporan Keuangan Pemerintah Pusat 2018)

2. Pajak Penghasilan adalah pajak yang dikenakan kepada orang pribadi atau badan atas penghasilan yang diterima atau diperoleh dalam satu Tahun Pajak. (Tjahjono, 1999)

3. Pengalihan hak adalah penyerahan kekuatan/kekuasaan (atas sesuatu benda) kepada badan hukum, orang, negara (pihak lain) (Ramli dan Putri, 2018)

4. Tanah merupakan bagian kerak bumi yang memiliki susunan dari mineral serta bahan organik. (Kurniawan, 2019)

5. Bangunan adalah konstruksi teknik yang ditanam atau dilekatkan dalam suatu lingkungan secara tetap, sebagian atau seluruhnya di atas atau di bawah permukaan tanah dan/atau perairan, berupa bangunan gedung dan/atau bukan gedung, digunakan atau dimaksudkan untuk menunjang atau mewadahi suatu penggunaan atau kegiatan manusia (Departemen PU, 2009)

- Undang-Undang Nomor 36 Tahun 2008 tentang Perubahan Keempat atas Undang-Undang Nomor 7 Tahun 1983 tentang Pajak Penghasilan

- Peraturan Pemerintah Nomor 34 Tahun 2016 tentang Pajak Penghasilan atas Penghasilan dari Pengalihan Hak atas Tanah dan/atau Bangunan, Perjanjian Jual Beli atas Tanah dan/atau Bangunan Berserta Perubahannya

- PER-18/PJ/2017 tentang Tata Cara Penelitian Bukti Pemenuhan Kewajiban Penyetoran Pajak Penghasilan dari Pengalihan Hak atas Tanah dan/atau Bangunan, Perjanjian Jual Beli atas Tanah dan/atau Bangunan Berserta Perubahannya

- PER-26/PJ/2018 tentang Perubahan atas Peraturan Direktur Jenderal Pajak Nomor PER18/PJ/2017 tentang Tata Cara Penelitian Bukti Pemenuhan Kewajiban Penyetoran PajakPenghasilan dari Pengalihan Hak atas Tanah dan/atau Bangunan, Perjanjian Jual Beli atas Tanah dan/atau Bangunan Berserta Perubahannya

* Corresponding author's e-mail: agusbandiyono@pknstan.ac.id 
Jurnal Akuntansi Berkelanjutan Indonesia - Vol. 4, No. 1, Jan 2021 - Bandiyono \& Fitriyani

1. Pembangunan Bandara di Kabupaten Kulon Progo, DIY menyebabkan harga tanah di Kabupaten Kulon Progo meningkat.

2. Terdapat peningkatan jumlah pengalihan hak atas tanah dan/atau bangunan di Kabupaten Kulon Progo

3. Terdapat potensi pajak penghasilan atas transaksi pengalihan hak atas tanah dan/atau bangunan di Kabupaten Kulon Progo

4. Upaya penggalian potensi yang dilakukan oleh KPP Pratama Wates untuk meningkatkan penerimaan pajak penghasilan dari transaksi pengalihan hak atas tanah dan/atau bangunan

5. Evaluasi upaya penggalian potensi yang telah dilakukan oleh KPP Pratama Wates

Evaluasi Terhadap Penggalian Potensi Pajak Penghasilan Dari Transaksi Pengalihan Hak Atas Tanah Dan/Atau Bangunan Di KPP Pratama Wates

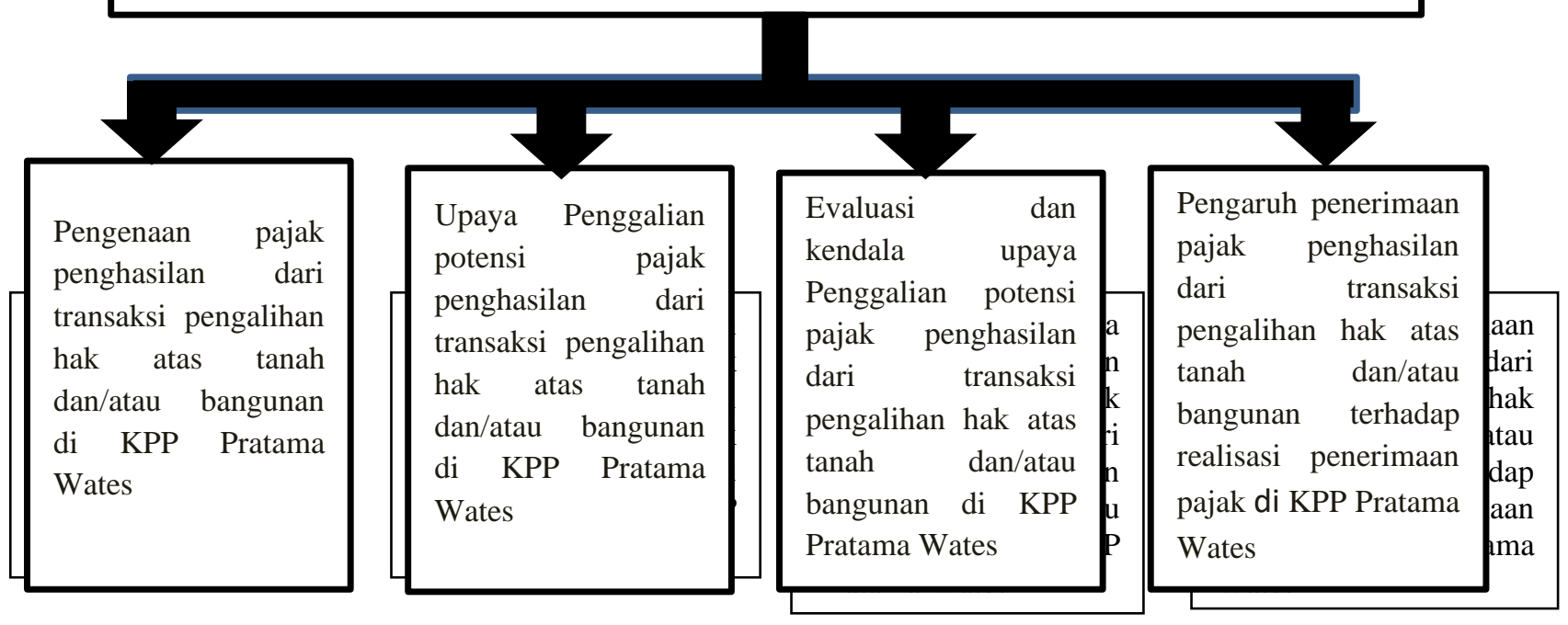

Sumber: Diolah oleh penulis

\section{Gambar 1.1 Kerangka Pemikiran}

\section{METODE RISET}

Metode penelitian yang digunakan dalam penelitian ini adalah metode penelitian deskriptif kualitatif dengan metode kepustakaan dan metode penelitian lapangan. Teknik pengumpulan data dalam penelitian ini dilakukan dengan tiga cara untuk memenuhi triangulasi teknik, di mana triangulasi teknik tersebut menurut Stainback sebagaimana dikutip oleh Sugiyono $(2015,397)$ bertujuan untuk meningkatkan pemahaman peneliti terhadap apa yang telah ditemukan. Mathinson sebagaimana yang dikutip Sugiyono $(2015,399)$ menjelaskan bahwa nilai dari teknik pengumpulan data dengan triangulasi adalah untuk mengetahui data yang diperoleh secara meluas, baik berbentuk konvergen, inkonsisten, ataupun kontradiktif. Tiga teknik pengambilan data tersebut yaitu: wawancara mendalam (in-depth interview); observasi partisipatif pasif; dan studi dokumen dan literature. Wawancara dilakukan dengan beberapa pihak yang berkaitan dengan permasalahan yang dibahas seperti pegawai seksi pelayanan dan Account Representative sehingga dapat memberikan informasi secara relevan dan akurat.

* Corresponding author's e-mail: agusbandiyono@pknstan.ac.id 
Jurnal Akuntansi Berkelanjutan Indonesia - Vol. 4, No. 1, Jan 2021 - Bandiyono \& Fitriyani

Teknik pengolahan data yang dilakukan dalam penelitian ini mengacu pada model Miles dan Huberman (1984). Miles dan Huberman sebagaimana yang dikutip oleh Sugiyono $(2015,404)$ menjelaskan bahwa aktivitas dalam analisis data kualitatif dilakukan secara interaktif dan berlangsung terus menerus sehingga datanya sudah jenuh. Aktivitas analisis data tersebut terbagi menjadi pengumpulan data (data collection), reduksi data (data reduction), penyajian data (data display), dan penarikan kesimpulan dan evaluasi (conclusions: drawing/verifying).

\section{ANALISIS DATA DAN PEMBAHASAN}

Penelitian dilakukan dengan didahului melalui pengambilan data ke lapangan / objek penelitian yaitu dengan wawancara mendalam (in-depth interview) kepada beberapa pihak yang berkaitan dengan permasalahan yang dibahas seperti pegawai seksi pelayanan dan Account Representative sehingga dapat memberikan informasi secara relevan dan akurat.; kemudian dilanjutkan dengan observasi partisipatif pasif dari penulis dengan mendatangi secara langsung ke Kantor Pelayanan Pajak terkait; serta dielaborasi dengan studi dokumen dan literatur terkait tema. Setelah itu, dilanjutkan dengan teknik pengolahan data yang dilakukan dalam penelitian ini mengacu pada model Miles dan Huberman (1984). Aktivitas analisis data tersebut terbagi menjadi pengumpulan data (data collection) dari data wawancara yang selanjutnya dilakukan reduksi data (data reduction), kemudian penyajian data (data display), dan penarikan kesimpulan dan evaluasi (conclusions: drawing/verifying).

\section{Pengenaan Pajak Penghasilan atas Penghasilan dari Transaksi Pengalihan Hak atas Tanah dan/atau Bangunan Di KPP Pratama Wates}

Pajak penghasilan dari transaksi pengalihan hak atas tanah dan/atau bangunan di KPP Pratama Wates diterapkan dengan berdasarkan kepada Peraturan Pemerintah Nomor 34 Tahun 2016 dan Peraturan Menteri Keuangan Nomor 261/PMK.03/2016. Di Kabupaten Kulon Progo, transaksi didominasi oleh orang pribadi yang mengalihkan tanah berupa pekarangan seperti lahan kosong, tegalan, atau sawah sehingga tarif pajak penghasilan yang sering digunakan adalah $2,5 \%$.

Berdasarkan PP No 34 Tahun 2016 yang menjadi wajib pajak adalah yang menerima penghasilan. Pajak penghasilan ini bersifat final dan dasar pengenaan pajaknya adalah nilai pengalihan yang sebenarnya atau seharusnya diterima. Pembayaran pajak dilakukan dengan penyetoran sendiri oleh Wajib Pajak sebagai pihak yang menerima/memperoleh penghasilan dari transaksi pengalihan hak atas tanah dan/atau bangunan paling lambat tanggal 15 (lima belas) bulan berikutnya setelah bulan diterimanya pembayaran. Menurut pengamatan narasumber yang merupakan Account Representative KPP Pratama Wates hampir tidak ditemui wajib pajak lalai dalam membayar pajak penghasilan final atas pengalihan hak atas tanah dan/atau bangunan ini dikarenakan terdapat kepentingan wajib pajak juga untuk segera membayar pajak agar akta pengalihan hak dapat ditandatangani

* Corresponding author's e-mail: agusbandiyono@pknstan.ac.id

http://openjournal.unpam.ac.id/index.php/JABI 
Jurnal Akuntansi Berkelanjutan Indonesia - Vol. 4, No. 1, Jan 2021 - Bandiyono \& Fitriyani

oleh pejabat yang berwenang mengingat tanpa adanya bukti pembayaran pajak penghasilan ini, akta pengalihan hak atas tanah dan/atau bangunan tidak dapat di tandatangani.

\section{Potensi Pajak Penghasilan dari Transaksi Pengalihan Hak atas Tanah dan/atau Bangunan Di KPP Pratama Wates}

KPP Pratama Wates memiliki target penerimaan pajak setiap tahunnya. Adanya target penerimaan pajak yang telah ditetapkan ini membuat KPP Pratama Wates harus mampu mengoptimalkan segala potensi perpajakan di berbagai sektor termasuk salah satunya adalah pajak penghasilan dari transaksi pengalihan hak atas tanah dan/atau bangunan. Berdasarkan hasil wawancara, Account Representative menuturkan bahwa pajak penghasilan dari pengalihan hak atas tanah dan/atau bangunan mampu memberikan kontribusi terhadap realisasi penerimaan KPP Pratama Wates. Pajak dari pengalihan hak atas tanah dan atau bangunan dinilai cukup potensial. Hal ini didukung oleh data dari Seksi Pengolahan Data dan Informasi mengenai penerimaan pajak penghasilan dari transaksi pengalihan hak atas tanah dan/atau bangunan di KPP Pratama Wates sebagai berikut:

\section{Tabel 4.1 Penerimaan Pajak Penghasilan dari Transaksi Pengalihan Hak atas tanah dan/atau Bangunan}

\begin{tabular}{rr}
\hline Tahun & Jumlah Penerimaan (Rp) \\
\hline 2015 & 10.260 .204 .538 \\
2016 & 11.783 .585 .232 \\
2017 & 12.897 .491 .008 \\
2018 & 9.479 .373 .402 \\
2019 & 8.579 .186 .495 \\
\hline mer: Seksi Pengolahan Data dan Informasi KPP Pratama Wates
\end{tabular}

Dari tabel di atas dapat diketahui bahwa pada tahun 2015 hingga 2019 pajak penghasilan dari transaksi pengalihan hak atas tanah dan/atau bangunan selalu berkontribusi terhadap penerimaan pajak KPP Pratama Wates.

Adanya potensi pajak penghasilan dari transaksi pengalihan hak atas tanah dan/atau bangunan dapat dikatakan semakin potensial didukung dengan adanya data yang memperlihatkan harga tanah di Kulon Progo yang naik secara drastis pada beberapa tahun terakhir. Hal ini disinyalir disebabkan oleh adanya proyek pembangunan bandara di Kabupaten Kulon Progo. Menurut Bupati Kabupaten Kulon Progo, Hasto Wardoyo, Nilai Jual Objek Pajak (NJOP) tanah di Kabupaten Kulon Progo naik hingga $70 \%$ setelah adanya pembangunan bandara.

Berkenaan dengan adanya proyek bandara di Kulon Progo, narasumber menuturkan bahwa jumlah transaksi pengalihan hak atas tanah dan/atau bangunan yang terjadi di Kulon Progo secara umum tidak dipengaruhi secara langsung oleh adanya proyek bandara. Hal tersebut dikarenakan transaksi pengalihan hak atas tanah dan/atau bangunan terjadi secara merata di seluruh wilayah Kulon Progo, tidak hanya terpusat di sekitar kawasan bandara. Namun disisi lain, Account Representative di KPP Pratama Wates, juga melihat adanya potensi pengalihan 
Jurnal Akuntansi Berkelanjutan Indonesia - Vol. 4, No. 1, Jan 2021 - Bandiyono \& Fitriyani

hak atas tanah dan/atau bangunan di Kulon Progo ini sebagai potensi yang temporary. Potensi temporary yang dimaksud oleh beliau berarti adanya tren pengalihan hak atas tanah dan/atau bangunan di kawasan sekitar bandara atau jalan-jalan utama sebagai suatu yang terjadi tidak seterusnya. Beliau juga menuturkan bahwa secara efek psikologis para pengusaha melihat bahwa kawasan bandara merupakan kawasan yang potensial untuk menjalankan usaha. Oleh karena itu, seharusnya adanya potensi dari pengalihan hak atas tanah dan/atau bangunan ini perlu mendapatkan perhatian lebih dalam upaya penggalian potensinya.

Dalam penggalian potensi pajak penghasilan dari transaksi pengalihan hak atas tanah dan/atau bangunan ini, yang menjadi fokus perhatian adalah sering ditemukannya harga pengalihan yang menurut Account Representative dapat dikatakan tidak wajar karena adanya perbedaan antara nilai pengalihan yang dilakukan oleh wajib pajak dengan data harga wajar tanah menurut Badan Pertanahan Negara, yang mana data dari BPN inilah yang menjadi acuan Account Representative menentukan nilai transaksi tersebut wajar atau tidak. Dalam melakukan penggalian potensi untuk mencari adanya tax gap, Account Representative menggunakan harga tanah menurut Badan Pertanahan Nasional (BPN), yang mana menurut pemaparan Account Representative di KPP Pratama Wates, nilai jual objek pajak yang digunakan oleh wajib pajak untuk menjadi dasar nilai pengalihan belum sesuai dengan harga wajar sesungguhnya.

\section{Upaya Penggalian Potensi Pajak Penghasilan dari Transaksi Pengalihan Hak atas Tanah dan/atau Bangunan Di KPP Pratama Wates}

Upaya penggalian potensi pajak penghasilan dari transaksi pengalihan hak atas tanah dan/atau bangunan di KPP Pratama Wates mengacu pada Peraturan Direktur Jenderal Nomor PER-18/PJ/2017 tentang Tata Cara Penelitian Bukti Pemenuhan Kewajiban Penyetoran Pajak Penghasilan dari Pengalihan Hak atas Tanah dan/atau Bangunan, Perjanjian Jual Beli atas Tanah dan/atau Bangunan Berserta Perubahannya dengan perubahan terakhir dalam PER-26/PJ/2018. Pada pasal 2 ayat (1) disebutkan bahwa Kantor Pelayanan Pajak melakukan penelitian terhadap bukti pemenuhan kewajiban penyetoran berupa penelitian formal dan material. Pada proses penelitian bukti pemenuhan kewajiban perpajakan inilah nantinya terdapat upaya dari KPP Pratama Wates untuk menggali potensi pajak penghasilan dari transaksi pengalihan hak atas tanah dan/atau bangunan ini. Wajib Pajak yang telah melakukan penyetoran pembayaran pajak penghasilan harus menyampaikan permohonan penelitian bukti pemenuhan kewajiban penyetoran pajak penghasilan ke KPP Pratama Wates.

Penelitian formal dilakukan oleh Seksi Pelayanan di KPP Pratama Wates. Penelitian formal ini, selain berpedoman pada PER-18/PJ/2016 dan perubahannya dalam PER-26/PJ/2018, sebagai petunjuk teknis di lapangan juga terdapat Standar Operasional Prosedur Nomor KPP30-0148 tentang Penyelesaian Penelitian Formal Bukti Pemenuhan Kewajiban Penyetoran Pajak Penghasilan atas Penghasilan dari Pengalihan Hak, dan Perubahan Perjanjian Pengikatan Jual Beli atas Tanah dan/atau Bangunan di Kantor Pelayanan Pajak yang ditetapkan tanggal 18 Desember 2018. Berdasarkan hasil wawancara dengan pelaksana Seksi 
Jurnal Akuntansi Berkelanjutan Indonesia - Vol. 4, No. 1, Jan 2021 - Bandiyono \& Fitriyani

Pelayanan KPP Pratama Wates, proses penelitian formal dimulai dengan Petugas Tempat Pelayanan Terpadu menerima berkas permohonan dari wajib pajak. Dalam melakukan pengecekan berkas, petugas pada seksi pelayanan sudah memiliki daftar berupa checklist kelengkapan dokumen-dokumen apa saja yang perlu dilampirkan untuk melakukan permohonan. Permohonan penelitian bukti pemenuhan kewajiban penyetoran pajak penghasilan dilakukan menggunakan surat permohonan yang telah ditandatangani penjual/pemberi hibah yang dilampiri dokumen-dokumen berikut ini:

a. SSP yang sudah tertera NTPN dan NTB/NTP/atau sarana administrasi lainnya yang disamakan dengan SSP

b. Surat pernyataan pengalihan hak atas tanah dan/atau bangunan atau perubahan perjanjian pengikatan jual beli atas tanah dan/atau bangunan

c. Fotokopi seluruh faktur/bukti penjualan, bukti transfer dan/atau fotokopi bukti pengiriman uang secara tunai yang telah ditandatangani pihak yang mengalihkan tanah dan/atau bangunan di atas materai atau apabila dalam hal hibah maka dilampirkan fotokopi surat Hibah

d. Fotokopi SPPT PBB/bukti penagihan PBB lainnya untuk tahun terakhir. Apabila terdapat perbedaan antara sertifikat tanah dan SPPT maka melampirkan Surat Keterangan Beda Nama dan Luas

e. Fotokopi sertifikat tanah

f. Fotokopi SPPD BPHTB yang sudah dilegalisasi atau sudah distempel pemerintah daerah tahun berjalan

g. Fotokopi KTP atau paspor dan fotokopi Kartu Keluarga pembeli dan penjual

h. Surat kuasa dan fotokopi KTP yang diberi kuasa untuk menyampaikan dan/atau dokumen (Optional)

i. $\quad$ Fotokopi brosur, pricelist dan PPJB (optional)

j. Surat pernyataan tidak wajib menggunakan NPWP dan Surat Keterangan Tidak Mampu (gakin) (optional)

k. Fotokopi pemberitahuan efektifnya pernyataan pendaftaran DIRE berbentuk KIK yang telah diterbitkan dan telah dilegalisasi oleh OJK (optional)

1. Keterangan dari OJK bahwa Wajib Pajak mengalihkan Real Estate bertransaksi dengan Special Purpose Company atau KIK dalam skema KIK tertentu (optional)

m. Surat pernyataan bermeterai yang menyatakan bahwa wajib pajak melakukan pengalihan real estate kepada special purpose company atau KIK dalam skema KIK tertentu (optional)

n. Setelah berkas diterima secara lengkap dan sesuai dengan checklist kelengkapan, berkas akan direkam ke dalam sistem kemudian petugas Tempat Pelayanan Terpadu akan memberikan Bukti Penerimaan Berkas (BPS) kepada Wajib Pajak serta akan mencetak Lembar Pengawasan Arus Dokumen (LPAD) untuk disatukan dengan berkas permohonan dan selanjutnya diteruskan kepada Kepala Seksi Pelayanan. Menurut hasil wawancara dengan pelaksana Seksi Pelayanan KPP Pratama Wates proses selanjutnya adalah kepala seksi pelayanan akan menugaskan pelaksana yang ditunjuk untuk menindaklanjuti berkas permohonan dengan melakukan

* Corresponding author's e-mail: agusbandiyono@pknstan.ac.id

http://openjournal.unpam.ac.id/index.php/JABI 
Jurnal Akuntansi Berkelanjutan Indonesia - Vol. 4, No. 1, Jan 2021 - Bandiyono \& Fitriyani

penelitian formal. Terhadap berkas permohonan, petugas peneliti akan memastikan kesesuaian:

a. identitas WP dalam bukti pemenuhan kewajiban penyetoran Pajak Penghasilan, dengan data di Direktorat Jenderal Pajak dan/atau fotokopi Kartu Tanda Penduduk atau Paspor;

b. jumlah Pajak Penghasilan yang telah disetor oleh WP, dengan Pajak Penghasilan yang seharusnya terutang berdasarkan surat pernyataan; dan

c. kode akun pajak, kode jenis setoran, Nomor Transaksi Penerimaan Negara (NTPN), dan jumlah PPh yang disetor, berdasarkan Surat Setoran Pajak (SSP) atau sarana administrasi lain yang dipersamakan dengan SSP, telah sesuai dengan data penerimaan pajak dalam Modul Penerimaan Negara (MPN).

Menurut hasil wawancara dengan pelaksana Seksi Pelayanan KPP Pratama Wates, apabila dari penelitian formal berkas permohonan tersebut dinyatakan lengkap dan sesuai maka petugas peneliti akan membuat konsep Surat Keterangan Penelitian Formal Bukti Pemenuhan Kewajiban Penyetoran Pajak Penghasilan. Namun, apabila ternyata berkas tidak lengkap dan/atau tidak sesuai, maka akan diusulkan konsep Surat Pemberitahuan Permohonan Penelitian Bukti Pemenuhan Kewajiban Penyetoran Pajak Penghasilan Tidak Lengkap dan/atau Tidak Sesuai. Kemudian, konsep surat tersebut akan diserahkan kepada Kepala Seksi Pelayanan. Lalu, konsep surat akan disetujui dan ditandatangani oleh Kepala Seksi Pelayanan. Dalam hal, terbit Surat Pemberitahuan Permohonan Penelitian Bukti Pemenuhan Kewajiban Penyetoran Pajak Penghasilan Tidak Lengkap dan/atau Tidak Sesuai, maka surat tersebut harus diambil langsung oleh Wajib Pajak/kuasanya di kantor pelayanan pajak dengan memperlihatkan Bukti Penerimaan Surat (BPS) atas permohonan yang ditujukan dan wajib pajak bisa kembali setelah melengkapi berkas permohonan. Sedangkan apabila terbit Surat Keterangan Penelitian Formal Bukti Pemenuhan Kewajiban Penyetoran Pajak Penghasilan, maka surat keterangan ini akan dicetak sebanyak 3 rangkap di mana untuk wajib pajak 1 (satu) lembar, untuk arsip 1 (satu) lembar dan 1 (satu) lembar nantinya diteruskan ke Seksi Ekstensifikasi dan Penyuluhan atau Seksi Pengawasan dan Konsultasi untuk dilakukan penelitian material. Dalam hal wajib pajak merupakan wajib pajak dalam wilayah kerja kantor lain maka penelitian material akan dilakukan oleh kantor pelayanan pajak yang bersangkutan sehingga berkas penelitian formal akan dikirim ke kantor pelayanan pajak yang bersangkutan. Menurut hasil wawancara dengan pelaksana Seksi Pelayanan KPP Pratama Wates, setelah penelitian formal selesai dilakukan, langkah selanjutnya adalah melakukan penelitian material. Penelitian material ini merupakan penelitian untuk mengetahui apakah nilai pengalihan yang menjadi dasar pengenaan pajak penghasilan dari transaksi pengalihan hak atas tanah dan/atau bangunan ini telah sesuai dengan harga wajar atau data yang dimiliki oleh KPP. Penelitian material ini dilakukan oleh Account Representative di seksi ekstensifikasi dan penyuluhan atau seksi pengawasan dan konsultasi. Dalam penelitian material ini masing-masing Account Representative memanfaatkan segala data yang tersedia untuk menggali adanya potensi pajak penghasilan dari 
Jurnal Akuntansi Berkelanjutan Indonesia - Vol. 4, No. 1, Jan 2021 - Bandiyono \& Fitriyani

transaksi pengalihan hak atas tanah dan/atau bangunan. Proses pelaksanaan penelitian material ini dilaksanakan berdasarkan Standar Operasional Prosedur (SOP) Nomor KPP60-0075 yang ditetapkan pada tanggal 18 Desember 2018. Berkas penelitian formal akan diteruskan oleh petugas peneliti formal ke Account Representative yang bersangkutan. Dalam hal wajib pajak yang bersangkutan telah memiliki NPWP maka akan diserahkan kepada Account Representative pengampu wajib pajak yang bersangkutan, dapat berada di Seksi Ekstensifikasi dan Penyuluhan atau Seksi Pengawasan dan Konsultasi. Sedangkan untuk wajib pajak yang belum memiliki NPWP maka akan diserahkan ke Account Representative di Seksi Ekstensifikasi dan Penyuluhan. Account Representative di KPP Pratama Wates memiliki wilayah kerja masing-masing. Pembagian wilayah kerja Account Representative merupakan wewenang dari kepala seksi masingmasing. Secara umum, wilayah kerja Account Representative dibagi berdasarkan kecamatan/kelurahan yang berada di wilayah kerja KPP Pratama Wates dengan memperhatikan sebaran potensi penerimaan. Setelah berkas diterima oleh Account Representative maka akan dilakukan analisis kewajaran terhadap nilai pengalihan yang tercantum dalam berkas permohonan dan membuat konsep Laporan Analisis Indikasi Ketidakwajaran terhadap nilai pengalihan yang kemudian akan dilanjutkan kepada Kepala Seksi. Kepala Seksi kemudian akan meneliti, menyetujui, dan menandatangani konsep Laporan Analisis Indikasi Ketidakwajaran Nilai Pengalihan untuk ditindaklanjuti oleh Account Representative yang bersangkutan. Dalam menentukan nilai kewajaran ini, Account Representative di KPP Pratama Wates menggunakan dasar nilai tanah menurut Badan Pertanahan Nasional (BPN) dan dapat juga bertindak sendiri menjadi penilai pajak dalam rangka penelitian material.

Penelitian material ini dilakukan dalam jangka waktu paling lama 6 (enam) bulan setelah penelitian formal bukti pemenuhan kewajiban penyetoran $\mathrm{PPh}$ selesai dilakukan. Setelah melakukan penilaian dan penelitian, Account Representative akan membuat konsep Laporan Hasil Penelitian yang selanjutnya akan diteruskan kepada Kepala Seksi. Kepala seksi kemudian akan meneliti, menyetujui, dan menandatangani konsep Laporan Hasil Penelitian serta meneruskan kepada Kepala KPP. Apabila Kepala KPP menyetujui konsep Laporan Hasil Penelitian tersebut, maka kemudian akan diteruskan kepada seksi terkait. Dalam hal tidak perlu ada tindak lanjut atas Laporan Hasil Penelitian atau dengan kata lain nilai pengalihan yang dilakukan oleh Wajib Pajak sesuai dengan harga pengalihan wajar, maka proses penelitian material ini selesai. Namun, dalam hal terdapat tax gap yang mengakibatkan Account Representative memiliki dugaan bahwa Wajib Pajak belum memenuhi kewajiban perpajakannya sesuai dengan ketentuan peraturan perundang-undangan perpajakan, maka Account Representative akan menggali data dan informasi dari wajib pajak melalui Surat Permintaan Penjelasan atas Data dan/atau Keterangan. Penyampaian Surat Permintaan Penjelasan atas Data dan/atau Keterangan di KPP Pratama Wates dilakukan berdasarkan Standar Operasional Prosedur Nomor SOP-KPP70-0165 Tentang Permintaan Penjelasan atas Data dan/atau Keterangan Kepada Wajib Pajak. Selain menggunakan cara pengiriman SP2DK, berdasarkan pertimbangan Kepala Seksi, dapat juga dilakukan dengan menyampaikan langsung kepada 
Jurnal Akuntansi Berkelanjutan Indonesia - Vol. 4, No. 1, Jan 2021 - Bandiyono \& Fitriyani

Wajib Pajak melalui Kunjungan (visit). Dalam beberapa kasus, menurut penuturan narasumber, selain mengirimkan SP2DK, Account Representive di KPP Pratama Wates juga pernah melakukan visit terkait dengan adanya dugaan mengenai belum dipenuhinya kewajiban perpajakan wajib pajak terkait pajak penghasilan dari pengalihan hak atas tanah dan/atau bangunan. Hal yang menjadi pertimbangan dari Kepala Seksi maupun Account Representative untuk melakukan visit atau tidak melihat pada adanya potensi penerimaan yang lebih tinggi daripada biaya untuk visit. Selain itu, juga memperhatikan keterjangkauan wilayah dan indikasi-indikasi lain seperti diduga akan terjadi pengulangan transaksi dengan harga di bawah harga wajar. Dalam kegiatan visit ini nantinya Account Representative akan menyampaikan data-data yang dipunyai dan memberikan edukasi kepada wajib pajak terkait dengan pemenuhan kewajiban perpajakannya. Jangka waktu yang diberikan untuk wajib pajak dalam menyampaikan penjelasan adalah 14 hari setelah penyampaian surat permintaan penjelasan. Dalam hal wajib pajak memberikan tanggapan maka Account Representative akan menindaklanjuti sesuai dengan jenis tanggapan yang diberikan. Account Representative akan mendokumentasikan tanggapan Wajib Pajak tersebut dalam berita acara. Dalam diskusi antara Account Representative dan Wajib pajak, masing-masing pihak akan memaparkan dasar nilai pengalihan yang digunakan dengan didukung data-data yang ada. Pemberian penjelasan ini sering kali menghasilkan adanya kesepakatan pembayaran kekurangan pajak oleh wajib pajak, namun tidak jarang juga bahwa wajib pajak mampu mempertahankan nilai pengalihan sesuai dengan yang telah dilaporkan misal dengan menunjukkan bukti transfer atau kuitansi. Namun, apabila dalam jangka waktu yang ditentukan wajib pajak tidak memberikan penjelasan yang diminta maka Account Representative dapat melakukan pengiriman SP2DK kembali, melakukan kunjungan (visit) dan usulkan pemeriksaan. Hal ini dilakukan berdasarkan Standar Operasional Prosedur Nomor SOP-KPP70-0164 tentang Tindak Lanjut Wajib Pajak yang Tidak Memberikan Tanggapan terhadap Surat Permintaan Penjelasan atas Data dan/atau Keterangan. Account Representative dalam ini akan membuat Berita Acara Tidak Dipenuhi Permintaan Penjelasan dan LHP2DK. Upaya terakhir yang dapat diambil oleh Account Representative adalah mengajukan Wajib Pajak tersebut untuk diperiksa. Namun dalam pengusulan pemeriksaan pajak ini Account Representative akan melihat potensi penerimaan pajak yang diperoleh dibandingkan dengan biaya yang akan dikeluarkan. Dalam kasus Wajib Pajak yang ditangani oleh Account Representative di Seksi Ekstensifikasi dan penyuluhan usulan pemeriksaan sangat jarang dilakukan dikarenakan kebanyakan Wajib Pajak yang mereka teliti adalah Wajib Pajak yang belum memiliki NPWP sehingga untuk mengajukan Wajib Pajak tersebut ke pemeriksaan perlu di terbitkan NPWP secara jabatan. Menurut narasumber, hal ini menjadi salah satu pertimbangan Account Representative di seksi Ekstensifikasi dan Penyuluhan untuk mengajukan wajib pajak tersebut ke pemeriksaan karena tidak efektif dan efisien. 
Jurnal Akuntansi Berkelanjutan Indonesia - Vol. 4, No. 1, Jan 2021 - Bandiyono \& Fitriyani

\section{Evaluasi Upaya Penggalian Potensi Pajak Penghasilan dari Transaksi Pengalihan Hak atas Tanah dan/atau Bangunan Di KPP Pratama Wates}

Berdasarkan hasil wawancara dengan Account Representative dan pelaksana Seksi Pelayanan di KPP Pratama Wates mengenai penerapan pajak penghasilan dari transaksi pengalihan hak atas tanah dan/atau bangunan di atas, dapat diketahui bahwa KPP Pratama Wates telah melakukan pengenaan pajak penghasilan sesuai dengan Peraturan Pemerintah Nomor 34 Tahun 2016 tentang Pajak Penghasilan atas Penghasilan dari Pengalihan Hak atas Tanah dan/atau Bangunan, Perjanjian Jual Beli atas Tanah dan/atau Bangunan Berserta Perubahannya. Selain itu juga dilakukan berdasarkan Peraturan Menteri Keuangan Nomor 261/PMK.03/2016 tentang Tata Cara Penyetoran, Pelaporan, dan Pengecualian Pengenaan Pajak Penghasilan Atas Penghasilan dari Pengalihan Hak Atas Tanah Dan/ Atau Bangunan, Dan Perjanjian Pengikatan Jual Beli Atas Tanah Dan/Atau Bangunan Beserta Perubahannya untuk mendukung PP 34 Tahun 2016. Kemudian, KPP Pratama Wates melakukan prosedur penelitian formal dan material terhadap berkas permohonan penelitian pemenuhan kewajiban penyetoran pajak penghasilan atas penghasilan dari pengalihan hak atas tanah dan/atau bangunan, yang berdasarkan hasil wawancara, dilakukan berdasarkan Peraturan Direktur Jenderal Nomor PER-18/PJ/2017 Tata Cara Penelitian Bukti Pemenuhan Kewajiban Penyetoran Pajak Penghasilan dari Pengalihan Hak atas Tanah dan/atau Bangunan, Perjanjian Jual Beli atas Tanah dan/atau Bangunan Berserta Perubahannya dengan perubahan terakhir dalam PER-26/PJ/2018.

Dalam penerapan PER-18/PJ/2017 sttd PER-26/PJ/2018 terkait penelitian formal, Pelaksana Seksi Pelayanan menuturkan bahwa, KPP Pratama Wates memiliki beberapa kebijakan tersendiri yang berupa tambahan dokumen yang perlu dilampirkan dalam permohonan bukti pemenuhan kewajiban penyetoran pajak penghasilan selain yang disebut dalam peraturan tersebut. Dokumendokumen tersebut antara lain adalah Surat Keterangan Tidak Mampu dalam hal wajib pajak tidak memiliki NPWP, SSPPD BPHTB yang harus sudah dilegalisasi pemerintah daerah, dan foto Koordinat Lokasi tanah. Permohonan penelitian bukti pemenuhan kewajiban penyetoran pajak penghasilan dari pengalihan hak atas tanah dan/atau bangunan memang dapat dilakukan oleh wajib pajak yang belum memiliki NPWP. Dalam PER-26/PJ/2018 dalam hal wajib pajak tidak memiliki NPWP maka cukup melampirkan Surat Pernyataan Tidak Wajib Menggunakan NPWP. Namun, dengan maksud melaksanakan prinsip kehati-hatian dan menjaring wajib pajak baru di KPP Pratama Wates, maka persyaratan ditambah dengan melampirkan Surat Keterangan Tidak Mampu sebagai pendukung adanya Surat Pernyataan Tidak Wajib Menggunakan NPWP. Selain itu, menurut PER26/PJ/2018 SPPD BPHTB yang dapat digunakan dalam permohonan penelitian bukti pemenuhan kewajiban penyetoran pajak penghasilan dari pengalihan hak atas tanah dan/atau bangunan tidak disebutkan harus mendapat legalisasi dari pemerintah daerah setempat. Namun, KPP Pratama Wates memiliki kebijakan bahwa SPPD BPHTB tersebut harus sudah dilegalisasi Pemerintah Daerah Setempat. Kebijakan ini diambil untuk menghindari adanya manipulasi nilai pengalihan tanah yang dilakukan oleh wajib pajak. Adanya tambahan-tambahan dokumen yang diperlukan dalam penelitian formal di KPP Pratama Wates tersebut 
Jurnal Akuntansi Berkelanjutan Indonesia - Vol. 4, No. 1, Jan 2021 - Bandiyono \& Fitriyani

telah diinformasikan kepada Wajib Pajak atau yang menjadi kuasa wajib pajak. Informasi ini disampaikan melalui adanya print out daftar dokumen-dokumen lampiran pengajuan permohonan yang disediakan bersamaan dengan Surat Permohonan Penelitian di tempat pelayanan terpadu KPP Pratama Wates. Oleh karena itu, berdasarkan penuturan pelaksana Seksi Pelayanan KPP Pratama Wates, jarang ditemui wajib pajak yang tidak menyampaikan berkas permohonannya secara lengkap. Kemudian, untuk mempermudah penelitian material oleh Account Representatif di tahap berikutnya, wajib pajak juga wajib melampirkan foto koordinat lokasi Tanah. Secara keseluruhan, pelaksanaan penelitian formal di KPP Pratama Wates telah dilakukan sesuai Standar Operasional Prosedur yang berlaku yaitu Standar Operasional Prosedur Nomor KPP30-0148 tentang Penyelesaian Penelitian Formal Bukti Pemenuhan Kewajiban Penyetoran Pajak Penghasilan atas Penghasilan dari Pengalihan Hak, dan Perubahan Perjanjian Pengikatan Jual Beli atas Tanah dan/atau Bangunan.

Setelah penelitian formal selesai dilakukan, berkas permohonan wajib pajak akan diteruskan kepada Account Representative untuk dilakukan penelitian material. Berdasarkan wawancara yang dilakukan dengan Account Representative di Seksi Ekstensifikasi dan Penyuluhan dan Seksi Pengawasan dan Konsultasi mengenai pelaksanaan penelitian material di KPP Pratama Wates, penelitian material yang dilakukan oleh KPP Pratama Wates, telah sesuai dengan PER18/PJ/2017 sttd PER-26/PJ/2018. Hal ini dibuktikan dengan dilaksanakannya pengujian terhadap setiap berkas yang masuk untuk memastikan kebenaran lokasi, luas tanah, dan/atau bangunan dan meneliti kebenaran serta kewajaran nilai pengalihan yang dilakukan Wajib Pajak seperti yang dijelaskan pada Pasal 7 ayat (1) PER-18/PJ/2017.

Selain itu, dalam pelaksanaan di lapangan, Account Representative di KPP Pratama Wates melakukan penelitian material sesuai dengan standar operasional prosedur KPP60-0075 tentang Penyelesaian Penelitian Material Bukti Pemenuhan Kewajiban Penyetoran Pajak Penghasilan Atas Penghasilan dari Pengalihan Hak Atas Tanah dan/atau Bangunan, dan Perubahan Perjanjian Pengikatan Jual Beli Atas Tanah dan/atau Bangunan. Hal ini dibuktikan dengan dilaksanakannya prosedur kerja secara runtut sesuai dengan alur pelaksanaan penelitian material pada poin nomor 10 dalam SOP KPP60-0075. Dalam wawancara yang dilakukan, Account Representative KPP Pratama Wates menuturkan bahwa, dalam melakukan penelitian material ini Account Representative sering kali menemukan nilai pengalihan yang tidak wajar. Dalam hal terjadi kasus tersebut, maka Account Representative akan melakukan upaya-upaya yang dapat dilakukan untuk menggali adanya potensi dari tax gap yang ditemukan. Upaya ini berupa pengiriman SP2DK kepada wajib pajak untuk menggali informasi lebih lanjut dari wajib pajak maupun melakukan kunjungan langsung (visit) ke keberadaan wajib pajak. Pelaksanaan pengiriman SP2DK ini dilakukan dengan mengikuti alur prosedur kerja dalam SOP-KPP70-0165 Tentang Permintaan Penjelasan atas Data dan/atau Keterangan Kepada Wajib Pajak. 
Jurnal Akuntansi Berkelanjutan Indonesia - Vol. 4, No. 1, Jan 2021 - Bandiyono \& Fitriyani

\section{Kendala-kendala penggalian potensi pajak penghasilan dari Transaksi Pengalihan Hak atas Tanah dan/atau Bangunan Di KPP Pratama Wates}

Berdasarkan hasil wawancara dengan narasumber, yang merupakan Pelaksana di Seksi Pelayanan dan Account Representative di Seksi Ekstensifikasi dan Penyuluhan dan Seksi Pengawasan dan Konsultasi, dalam melakukan upaya penggalian potensi pajak penghasilan dari transaksi pengalihan hak atas tanah dan/atau bangunan di KPP Pratama Wates, seperti yang telah dipaparkan dalam pembahasan sebelumnya, sering kali mengalami kendala. Kendala-kendala yang terjadi dalam upaya penggalian potensi ini dinilai cukup menghambat upaya optimalisasi adanya potensi dari adanya pengalihan hak atas tanah dan/atau bangunan. Berdasarkan hasil wawancara Account Representative di KPP Pratama Wates dapat diketahui bahwa, hal yang sering menjadi kendala dalam melakukan upaya penggalian potensi ini adalah mengenai komunikasi dengan wajib pajak dan akses data. Ketika penelitian material menemukan adanya indikasi harga pengalihan yang tidak wajar, maka atas wajib pajak tersebut akan dikirimkan SP2DK/kunjungan (visit). Namun, tidak jarang dialami bahwa wajib pajak ini tidak memberikan respons terhadap permintaan penjelasan tersebut. Menurut narasumber, hal ini dapat disebabkan 2 (dua) kemungkinan. Pertama, Wajib Pajak tidak tahu apa yang harus dia lakukan dengan surat tersebut. Dalam mengalihkan hak atas tanah dan/atau bangunannya, wajib pajak kebanyakan menguasakan urusan perpajakan dan administrasi secara keseluruhan kepada PPAT/Notaris sehingga Wajib Pajak menganggap semua urusan administrasi telah diselesaikan oleh notaris. Kedua, adanya keengganan wajib pajak untuk membayar pajak sehingga menyembunyikan informasi yang dimiliki. Dalam hal ini, Account Representative telah mencoba menghubungi wajib pajak melalui nomor telepon yang telah dicantumkan namun beberapa kali ditemui bahwa nomor tersebut tidak memberi respons. Selain itu, upaya yang dilakukan adalah melakukan kunjungan (visit) dengan tetap memegang prinsip efisiensi. Selanjutnya, kendala yang dialami dalam melakukan penggalian potensi ini adalah adanya keterbatasan akses data yang lebih mendalam untuk mendukung penjelasan yang diberikan Wajib Pajak. Dalam hal wajib pajak memberikan penjelasan bahwa yang sebenarbenarnya nilai pengalihan ialah seperti yang dilaporkan, Account Representative belum memiliki akses seperti melihat mutasi rekening Wajib Pajak dan menelusuri kekayaan wajib pajak secara mendalam. Sehingga adanya potensi pajak ini terkendala dalam penelusuran lebih jauhnya. Selain itu, berdasarkan hasil wawancara, Account Representative di Seksi Ekstensifikasi dan Penyuluhan mengungkapkan bahwa beliau mengalami kendala tersendiri mengenai berkasberkas permohonan yang diajukan oleh wajib pajak yang tidak memiliki NPWP. Ketika Account Representative di seksi Ekstensifikasi dan Penyuluhan melakukan penelitian material dan menemukan adanya indikasi harga pengalihan yang tidak wajar, untuk melakukan upaya lebih lanjut sering dirasa tidak efisien. Hal ini dikarenakan wajib pajak tersebut harus diterbitkan NPWP secara jabatan terlebih dahulu. Menurut narasumber, kebanyakan mereka yang tidak memiliki NPWP ini adalah para petani/buruh sehingga, narasumber melihat bahwa nanti kedepannya potensi yang ada sangat kecil.

* Corresponding author's e-mail: agusbandiyono@pknstan.ac.id

http://openjournal.unpam.ac.id/index.php/JABI 
Jurnal Akuntansi Berkelanjutan Indonesia - Vol. 4, No. 1, Jan 2021 - Bandiyono \& Fitriyani

\section{KESIMPULAN DAN SARAN}

Pengenaan Pajak Penghasilan atas penghasilan dari transaksi pengalihan hak atas tanah dan/atau bangunan di KPP Pratama Wates dilakukan berdasarkan Peraturan Pemerintah Nomor 34 Tahun 2016 tentang Pajak Penghasilan atas Penghasilan dari Pengalihan Hak atas Tanah dan/atau Bangunan, Perjanjian Jual Beli atas Tanah dan/atau Bangunan Berserta Perubahannya serta aturan aturan lain dibawahnya seperti Peraturan Menteri Keuangan Nomor 261/PMK.03/2016.

Potensi pajak dari transaksi pengalihan hak atas tanah dan/atau bangunan dapat dikatakan cukup potensial karena selalu memberikan kontribusi terhadap realisasi penerimaan pajak KPP Pratama Wates secara keseluruhan. Berkenaan dengan adanya kenaikan Nilai Jual Objek Pajak di Kulon Progo merupakan potensi yang cukup besar dan dilihat sebagai suatu potensi yang temporary. Selain itu, potensi yang dapat digali oleh Account Representative di KPP Pratama Wates adalah berasal dari adanya tax gap yang ditemukan dikarenakan ada perbedaan nilai pengalihan menurut data yang ada di kantor dengan nilai pengalihan yang dinyatakan oleh Wajib Pajak.Melihat adanya potensi penerimaan pajak penghasilan dari pengalihan hak atas tanah dan/atau bangunan, KPP Pratama Wates melakukan beberapa upaya untuk mengoptimalisasi adanya potensi tersebut. Upaya penggalian potensi ini mengoptimalkan proses penelitian formal dan material terhadap pemenuhan kewajiban perpajakan dari berkas yang telah disampaikan oleh Wajib Pajak sesuai dengan Peraturan Direktur Jenderal Nomor PER-18/PJ/2017.

Secara keseluruhan penerapan pengenaan pajak penghasilan dan upaya penggalian potensi dari transaksi pengalihan hak atas tanah dan/atau bangunan di KPP Pratama Wates telah dilakukan sesuai peraturan perundang-undangan dan standar operasional prosedur yang ada. Dalam melakukan upaya penggalian potensi dari transaksi pengalihan hak atas tanah dan/atau bangunan di KPP Pratama Wates ditemui beberapa kendala seperti kesulitan berkomunikasi dengan Wajib Pajak, kurangnya kewenangan dalam akses data Wajib Pajak yang lebih mendalam terkait dengan kebenaran nilai transaksi yang dinyatakan Wajib Pajak, masih banyak berkas permohonan penelitian yang dilakukan oleh Wajib Pajak yang belum memiliki NPWP sehingga kesulitan dalam dilakukan tindak lanjut, dan adanya kendala dari peraturan yang ada.

\section{DAFTAR PUSTAKA}

Agustina, N. K. A. R. (2017). Validasi Pajak Terkait Dengan Akta Yang Dibuat Dihadapan Notaris Menurut Pp No. 34 Tahun 20116. Jurnal Kertha Wicaksana, 1(5).

Alwi, H. (2007). Kamus Besar Bahasa Indonesia. Jakarta: Balai Pustaka.

Bandiyono, Agus. (2017). Tata Cara Pemeriksaan Pajak Pada Seksi Pemeriksaan. Jurnal Demokrasi Dan Otonomi Daerah 15, no. 3.

* Corresponding author's e-mail: agusbandiyono@pknstan.ac.id http://openjournal.unpam.ac.id/index.php/JABI 
Jurnal Akuntansi Berkelanjutan Indonesia - Vol. 4, No. 1, Jan 2021 - Bandiyono \& Fitriyani

Bandiyono, Agus, dan Dinda Rahmawati. (2018) Evaluasi Pelaksanaan Tugas Dan Fungsi Kantor Pelayanan Pajak Dalam Pengolahan Surat. Jurnal Kebijakan Publik 9, no. 2: 79-88.

Bappeda Provinsi DIY. (t.thn.). Bappeda Provinsi DIY. Dipetik Desember 30, 2019, dari http://bappeda.jogjaprov.go.id/dataku/data_dasar/cetak/413laju-pertumbuhan-ekonomi

Buitelaar, E. (2004). A transaction-cost analysis of the land development process. Urban studies, 41(13), 2539-2553.

Damanik. (2009). Pengaruh Kenaikan NJOP terhadap Tingkat Penerimaan PBB pada KP PBB Pratama Medan Belawan. Medan: Universitas Sumatera Utara.

DMPT Kulon Progo. (2019, Oktober 16). Pemerintah Kabupaten Kulon Progo. Dipetik Desember 8, 2019, dari https://dpmpt.kulonprogokab.go.id/article436-pertumbuhan-ekonomi-kulonprogo-tembus-1084-persen.html

Hardiyatmo, H. C. (1992). Mekanika Tanah. Jakarta: Gramedia.

Irawan, F. (2018). Dampak Penerapan Peraturan Pemerintah Nomor 34 Tahun 2016 (Studi Kasus di Kantor Pelayanan Pajak Pratama Kepanjen). Keberlanjutan: Jurnal Manajemen dan Jurnal Akuntansi, 2(2), 589-601.

Kementerian Keuangan. (2019). Laporan Keuangan Pemerintah Pusat Tahun 2018 (audited). Jakarta: Sekretariat Negara.

Kurniawan, A. (2019, Desember 24). gurupendidikan.com. Dipetik Februari 4, 2020, dari https://www.gurupendidikan.co.id/pengertian-tanah/

Nahak, S., Iswara, B. M., \& Mahendrawati, N. L. (2019). Kepastian Hukum Pengenaan Pajak Penghasilan Transaksi Jual Beli Tanah dan/atau Bangunan. Journal Warmadewa Prasada, 42-51.

Newswire. (2018, Maret 5). BISNIS.COM. Dipetik Desember 8 , 2019, dari https://ekonomi.bisnis.com/read/20180305/98/746129/gara-gara-bandaranew-yogyakarta-njop-di-kulon-progo-naik-70

Nugroho, A. (2018, MAret 5). Tribun Jogja. Dipetik Desember 8, 2019, dari https://jogja.tribunnews.com/2018/03/05/tidak-ada-lagi-njop-tanah-dibawah-rp10000-di-kulonprogo?page=3

Nuradila, R. F., \& Wibowo, R. A. (2018). Tax Minimization sebagai Pemoderasi Hubungan antara Tunneling Incentive, Bonus Mechanism dan Debt Convenant dengan Keputusan Transfer Pricing. Journal of Islamic Finance and Accounting, 1-14.

OnlinePajak. (2018, Oktober 3). Online Pajak. Dipetik Desember 9, 2019, dari https://www.online-pajak.com/pajak-penjualan-tanah

* Corresponding author's e-mail: agusbandiyono@pknstan.ac.id http://openjournal.unpam.ac.id/index.php/JABI 
Jurnal Akuntansi Berkelanjutan Indonesia - Vol. 4, No. 1, Jan 2021 - Bandiyono \& Fitriyani

Pratama, K. B. (2019). Analisis penerapan Peraturan Pemerintah Nomor 34 TAHUN 2016 di Kabupaten Karanganyar (Studi kasus KPP Pratama Karanganyar).

Ramli, T. S., \& Putri, S. A. (2018). Tinjauan Hukum Perbedaan Pengalihan Hak Paten dengan Perjanjian Lisensi pada Hukum Perdata. Dialogia Iuridica, 96-100.

Resmi, S. (2011). Perpajakan Teori dan Kasus Edisi 6. Jakarta: Salemba Empat.

Resmi, S. (2012). Perpajakan. Jakarta: Salemba Empat.

Rum, M., \& Kusumawardani, A. (2020). Industrial Growth and Environmental Resource toward the Tax Potential: A Case Study in South Sulawesi Province. The Journal of Asian Finance, Economics and Business (JAFEB), 7(10), 201-210.

Satori, D., \& Komariah, A. (2013). Metodologi Penelitian Kualitatif. Bandung: Alfabeta.

Shahab, S., \& Viallon, F. X. (2019). A transaction-cost analysis of Swiss land improvement syndicates. Town Planning Review, 90(5), 545-566.

Susyanti, J., \& Wahono, B. (2018). Analisa Kinerja Keuangan Perusahaan Real Estate Dan Property Sebelum Dan Selama Diberlakukannya PP No. 34 Tahun 2016. Jurnal Ilmiah Riset Manajemen, 7(03).

Sugiono. (2013). Metode Penelitian Kualitatif. Bandung: Alfabeta.

Sunyoto, D. (2016). Metodologi Penelitian Akuntansi. Bandung: PT Refika.

Tjahjono, A. (1999). Perpajakan. Yogyakarta: UPPAM PYKPN.

Waluyo. (2011). Perpajakan Indonesia. Jakarta: Salemba Empat.

Warsito, L. (2016). Potensi Korupsi dalam Kebijakan Validasi Pajak Penjualan atas Tanah dan/atau Bangunan. Jurnal Pembaharuan Hukum, 363-369.

Widi. (2017, Agustus 27). OKEZONE.COM. Dipetik Desember 8, 2019, dari https://economy.okezone.com/read/2017/08/27/320/1763983/wah-proyekbandara-kulon-progo-bakal-tambah-pendapatan-pemda

Wikipedia. (t.thn.). Wikipedia. Dipetik Februari 20, 2020, dari https://id.wikipedia.org/wiki/Kabupaten_Kulon_Progo

Republik Indonesia. (1985). Undang-Undang Republik Indonesia Nomor 12 Tahun 1985 Tentang Pajak Bumi dan Bangunan. Jakarta: Sekretariat Negara.

Republik Indonesia. (2008). Undang-Undang Republik Indonesia Nomor 36 Tahun 2008 tentang Perubahan Keempat atas Undang-Undang Nomor 7 Tahun 1983 tentang Pajak Penghasilan. Jakarta: Sekretariat Negara.

Direktorat Jenderal Pajak . (2016). Peraturan Pemerintah Republik Indonesia Nomor 34 Tahun 2016 Tentang Pajak Penghasilan dari Pengalihan Hak 
Jurnal Akuntansi Berkelanjutan Indonesia - Vol. 4, No. 1, Jan 2021 - Bandiyono \& Fitriyani

atas Tanah dan/atau Bangunan, Perjanjian Jual Beli atas Tanah dan/atau Bangunan Beserta Perubahannya. Jakarta: Sekretariat Negara.

Direktorat Jenderal Pajak. (2017). Peraturan Direktur Jenderal Pajak Nomor PER-18/PJ/2017 tentang Tata Cara Penelitian Bukti Pemenuhan Kewajiban Penyetoran Pajak Penghasilan atas Penghasilan dari Pengalihan Hak. Jakarta: Sekretariat Negara.

Direktorat Jenderal Pajak. (2018). Peraturan Direktur Jenderal Pajak Nomor PER-26/PJ/2018 tentang Perubahan atas Peraturan Direktur Jenderal Pajak Nomor PER-18/PJ/2017 tentang Tata Cara Penelitian Bukti Pemenuhan Kewajiban Penyetoran Pajak Penghasilan atas Penghasilan dari Pengalihan Hak. Jakarta: Sekretariat Negara. 